\title{
Radiopacity evaluation of root canal sealers containing calcium hydroxide and MTA
}

\section{Juliane Maria Guerreiro- Tanomaru(a) \\ Marco Antonio Húngaro Duarte(b) \\ Marcelo Gonçalves (c) \\ Mario Tanomaru-Filho(d)}

(a) PhD, Assistant Professor; (d)PhD, Associate Professor - Department of Restorative Dentistry, School of Dentistry of Araraquara, São Paulo State University, Araraquara, SP, Brazil.

(b) PhD, Assistant Professor, Department of Endodontics, Sagrado Coração University, Bauru, SP, Brazil.

(c) PhD, Assistant Professor, Department of Radiology, School of Dentistry of Araraquara, São Paulo State University, Araraquara, SP, Brazil.

\section{Corresponding author:}

Mario Tanomaru-Filho

Rua Humaitá, 1901, apto. 182

Araraquara - SP - Brazil

CEP: 14801-385

E-mail: tanomaru@uol.com.br

Received for publication on Feb 03, 2008

Accepted for publication on Jun 30, 2008

\begin{abstract}
The purpose of this study was to evaluate the radiopacity of root canal sealers containing calcium hydroxide and MTA (Acroseal, Sealer 26, Sealapex, Endo CPM Sealer, Epiphany and Intrafill). Five discshaped specimens $(10 \times 1 \mathrm{~mm})$ were fabricated from each material, according to the ISO 6876/2001 standard. After setting of the materials, radiographs were taken using occlusal film and a graduated aluminum stepwedge varying from 2 to $16 \mathrm{~mm}$ in thickness. The dental X-ray unit (GE1000) was set at $50 \mathrm{kVp}, 10 \mathrm{~mA}, 18$ pulses/s and distance of $33.5 \mathrm{~cm}$. The radiographs were digitized and the radiopacity compared to that of the aluminum stepwedge using VIXWIN-2000 software (Gendex). The data $(\mathrm{mmAl})$ were analyzed statistically by ANOVA and Tukey's test at the $5 \%$ significance level. Epiphany and Intrafill presented the highest radiopacity values $(8.3 \mathrm{mmAl}$ and $7.5 \mathrm{mmAl}$ respectively, $\mathrm{p}<0.05)$ followed by Sealer $26(6.3 \mathrm{mmAl})$, Sealapex $(6.1 \mathrm{mmAl})$ and Endo CPM Sealer $(6 \mathrm{mmAl})$. Acroseal was the least radiopaque material $(4 \mathrm{mmAl}$, $\mathrm{p}<0.05)$. In conclusion, the calcium hydroxide- and MTA-containing root canal sealers had different radiopacities. However, all materials presented radiopacity values above the minimum recommended by the ISO standard.
\end{abstract}

Descriptors: Radiology; Radiography; Root canal obturation. 


\section{Introduction}

Root canal filling materials should present sufficient radiopacity to be distinguished from the adjacent anatomical structures. ${ }^{1-4}$ Eliasson, Haasken ${ }^{5}$ (1979) established a comparison standard for radiopacity studies in which the optical radiographic densities of several impression materials were measured and the values expressed as an equivalent thickness of aluminum capable of producing similar radiographic density.

Beyer-Olsen, Orstavik ${ }^{1}$ (1981) included in their studies a reproducible comparison standard using a 2-mm-increment aluminum stepwedge to determine the radiopacity of several root canal sealers. Tanomaru-Filho et al. ${ }^{6}$ (2007) evaluated the radiopacity of five root canal sealers (AH Plus, Intrafill, Roeko Seal, Epiphany and EndoRez) using a graduated aluminum stepwedge varying from 2 to $16 \mathrm{~mm}$ in thickness. AH Plus and Epiphany were the most radiopaque materials, followed by EndoRez, Roeko Seal and Intrafill.

In the search for materials with adequate biocompatibility, the addition of calcium hydroxide to the formulation of root canal sealers has been investigated. ${ }^{7,8}$ However, the presence of calcium hydroxide tends to decrease the radiopacity of these materials. ${ }^{9}$

Sealapex (SybronEndo, Orange, CA, USA) was the first calcium hydroxide-based root canal sealer introduced to market with good biological properties. $^{8,10}$ Sealapex's manufacturer has recently modified its formulation by adding bismuth trioxide to improve its radiopacity properties and increase its shelf life.

Other calcium hydroxide-containing root canal sealers have been developed, such as Sealer 26 and, more recently, Acroseal. These sealers present epoxy resin in their composition, being derived from $\mathrm{AH}$ 26 sealer.

The recently launched Epiphany sealer is part of the Epiphany/Resilon system. It has a resinous characteristic and its formulation is based on methacrylates in addition to calcium hydroxide. ${ }^{11}$ This material has been shown to have a good biological behavior. $^{12}$

Mineral trioxide aggregate (MTA) has been widely indicated for several applications in Endodontics, among which sealing of perforations, pulp capping, pulpotomy, apexification and use as a retrofilling material. It is basically composed of Portland cement, ${ }^{13}$ whose main components are tricalcium silicate, dicalcium silicate, tricalcium aluminate, tetracalcium aluminoferrate and hydrated calcium sulfate. MTA also presents bismuth oxide, which is responsible for its radiopacity. According to Holland et al. ${ }^{14,15}$ (1999, 2001), MTA and calcium hydroxide share the same mechanism of action. A new MTAbased root canal sealer has been recently launched under the brand name Endo CPM Sealer. Its basic composition is the same as that of MTA, the only difference being the addition of barium sulfate and calcium chloride. ${ }^{16}$

The purpose of this study was to compare the radiopacity of root canal sealers containing calcium hydroxide (Acroseal, Sealer 26, Sealapex, Epiphany) or MTA (Endo CPM Sealer) and a traditional zinc oxide and eugenol-based root canal sealer (Intrafill), according to the ISO 6876/2001 standard (2001), which recommends that root canal filling materials should be at least as radiopaque as $3 \mathrm{~mm}$ of aluminum thickness.

\section{Material and Methods}

Six root canal sealers were evaluated in this study: Acroseal, Sealer 26, Sealapex, Endo CPM Sealer, Epiphany and Intrafill (Table 1).

All materials were prepared according to the manufacturers' instructions. For specimen preparation, impressions were taken from metallic matrices using a light-bodied silicone-based impression material. The moulds were filled with the tested materials and stored in a moist chamber (incubator) at $37^{\circ} \mathrm{C}$ until complete set of the cements. Five specimens measuring $10 \mathrm{~mm}$ in diameter and $1 \mathrm{~mm}$ in thickness were fabricated from each material.

Thereafter, the specimens were placed onto 5 occlusal radiographic films (Insight; Kodak Comp., Rochester, NY, USA) next to a graduated aluminum stepwedge with thickness ranging from 2 to $16 \mathrm{~mm}$ (in $2 \mathrm{~mm}$-increments) and exposed using a GE-1000 X-ray unit (General Electric, Milwaukee, WI, USA) operating at $50 \mathrm{kVp}, 10 \mathrm{~mA}, 18$ pulses/second, and 


\begin{tabular}{|c|c|c|c|}
\hline \multirow{7}{*}{$\begin{array}{l}\text { Table } 1 \text { - Tested materials, } \\
\text { composition and manufacturers. }\end{array}$} & Material & Composition & Manufacturer \\
\hline & Acroseal & $\begin{array}{l}\text { Base Paste: } 2 \mathrm{~g} \text { glycyrrhetic acid, } 25 \mathrm{~g} \text { methenamine, } \\
\text { radiopaque excipient q.s.p. } 100 \mathrm{~g} \\
\text { Catalyst Paste: } 28 \mathrm{~g} \text { calcium hydroxide, } 17 \mathrm{~g} \text { bisphenol } \\
\text { A diglycidyl ether, radiopaque excipient q.s.p. } 100 \mathrm{~g}\end{array}$ & $\begin{array}{l}\text { Septodont, Sant-Maur-des } \\
\text { Fossés, Cedex, France }\end{array}$ \\
\hline & Sealer 26 & $\begin{array}{l}\text { Powder: bismuth trioxide, calcium hydroxide, } \\
\text { hexamethylenetetramine and titanium dioxide } \\
\text { Paste: bisphenol epoxy resin }\end{array}$ & $\begin{array}{l}\text { Denstply Indústria } \\
\text { e Comércio Ltda., } \\
\text { Petrópolis, RJ, Brazil }\end{array}$ \\
\hline & Sealapex & $\begin{array}{l}20 \% \text { calcium oxide, } 2.5 \% \text { zinc oxide, } 29 \% \text { bismuth } \\
\text { trioxide, } 3 \% \text { silicon particles, } 20 \% \text { titanium dioxide, } 1 \% \\
\text { zinc stearate, } 3 \% \text { tricalcium phosphate, isobutyl salicylate } \\
+ \text { methyl salicylate }+39 \% \text { pigment }\end{array}$ & $\begin{array}{l}\text { SybronEndo - Sybron } \\
\text { Dental Specialties, } \\
\text { Glendona, CA, USA }\end{array}$ \\
\hline & $\begin{array}{l}\text { Endo CPM } \\
\text { Sealer }\end{array}$ & $\begin{array}{l}\text { MTA: silicon dioxide, calcium carbonate, bismuth } \\
\text { trioxide, barium sulfate, propyleneglycol alginate, sodium } \\
\text { citrate, calcium chloride, active ingredients }\end{array}$ & $\begin{array}{l}\text { EGEO S.R.L. Bajo Licencia } \\
\text { MTM Argentina S.A., } \\
\text { Buenos Aires, Argentina }\end{array}$ \\
\hline & Epiphany & $\begin{array}{l}\text { UDMA, PEGDMA, EBPADMA, BISGMA and methacrylate } \\
\text { resins; barium borosilicate glasses treated with silane; } \\
\text { barium sulfate; silica; calcium hydroxide; bismuth } \\
\text { oxychloride with amines; peroxides; photopolymerization } \\
\text { initiator; stabilizers and pigments }\end{array}$ & $\begin{array}{l}\text { Pentron Clinical } \\
\text { Technologies, LLC., } \\
\text { Wallingford, CT, USA }\end{array}$ \\
\hline & Intrafill & $\begin{array}{l}\text { Zinc oxide, hydrogenated colophony, colophony, bismuth } \\
\text { subcarbonate, barium sulfate, anhydrous disodium } \\
\text { borate, eugenol }\end{array}$ & $\begin{array}{l}\text { SSWhite, Rio de Janeiro, } \\
\text { RJ, Brazil }\end{array}$ \\
\hline
\end{tabular}

focus-film distance of $33.5 \mathrm{~cm}$. The radiographs were digitized using a desktop scanner (SnapScan 1236; Agfa, Deutschland) and the digitized images were imported into the VIXWIN 2000 software (Gendex, Deplanes, IL, USA). The equal-density tool was used to identify equal-density areas, allowing comparison among the different materials' densities and the radiopacity of the different thicknesses of the aluminum stepwedge. Using the computer mouse, the specimen area was delimited in each radiographic image in order to determine which thickness of the aluminum stepwedge was detected by the software as presenting the same radiographic density as the sample. The optical density values may range from 0 to 255 , according to VIXWIN software. After determining the optical density value for each specimen, the following equation was applied to convert the values into $\mathrm{mmAl}$ :

$\underset{(\mathrm{mm})}{\mathrm{Al} \text { equivalent }}=\begin{gathered}\text { Radiopacity of } \\ \text { the specimen }\end{gathered} \times \frac{\begin{array}{c}\text { Al thickness of the } \\ \text { aluminum stepwedge }(\mathrm{mm})\end{array}}{\begin{array}{l}\text { Radiopacity of } \\ \text { the stepwedge }\end{array}}$

This equation determined the equivalence of each material's radiopacity to a particular thickness of the aluminum stepwedge, expressed in $\mathrm{mm}$. The results were analyzed by calculating the arithmetic mean of five measurements per specimen. The data were submitted to statistical analysis by ANOVA and Tukey's test at the 5\% significance level.

\section{Results}

The radiopacity values are presented in Graph 1. Epiphany and Intrafill had the highest radiopacity values among the tested materials $(\mathrm{p}<0.05)$ (8.3 mmAl and $7.5 \mathrm{mmAl}$, respectively) followed by Sealer $26(6.3 \mathrm{mmAl})$, Sealapex $(6.1 \mathrm{mmAl})$ and Endo CPM Sealer $(6 \mathrm{mmAl})$. Acroseal was the least radiopaque material $(4 \mathrm{mmAl}, \mathrm{p}<0.05)$.

\section{Discussion}

Tagger, Katz ${ }^{17}$ (2003) developed a method for analysis of the radiopacity of endodontic sealers using standardized samples radiographed next to an aluminum stepwedge. In this method, the radiographs are digitized and the specimens' radiopacity is compared to that of the aluminum stepwedge using computer software. The comparative evaluation of digitized radiographic images using an imageanalysis software has been shown to determine the 
Graph 1 - Radiopacity means and standard deviation for the tested materials and results of the Tukey HSD post-hoc test $(\alpha=.05)$. Same letters indicate that the groups were not significantly different $(p>.05)$.

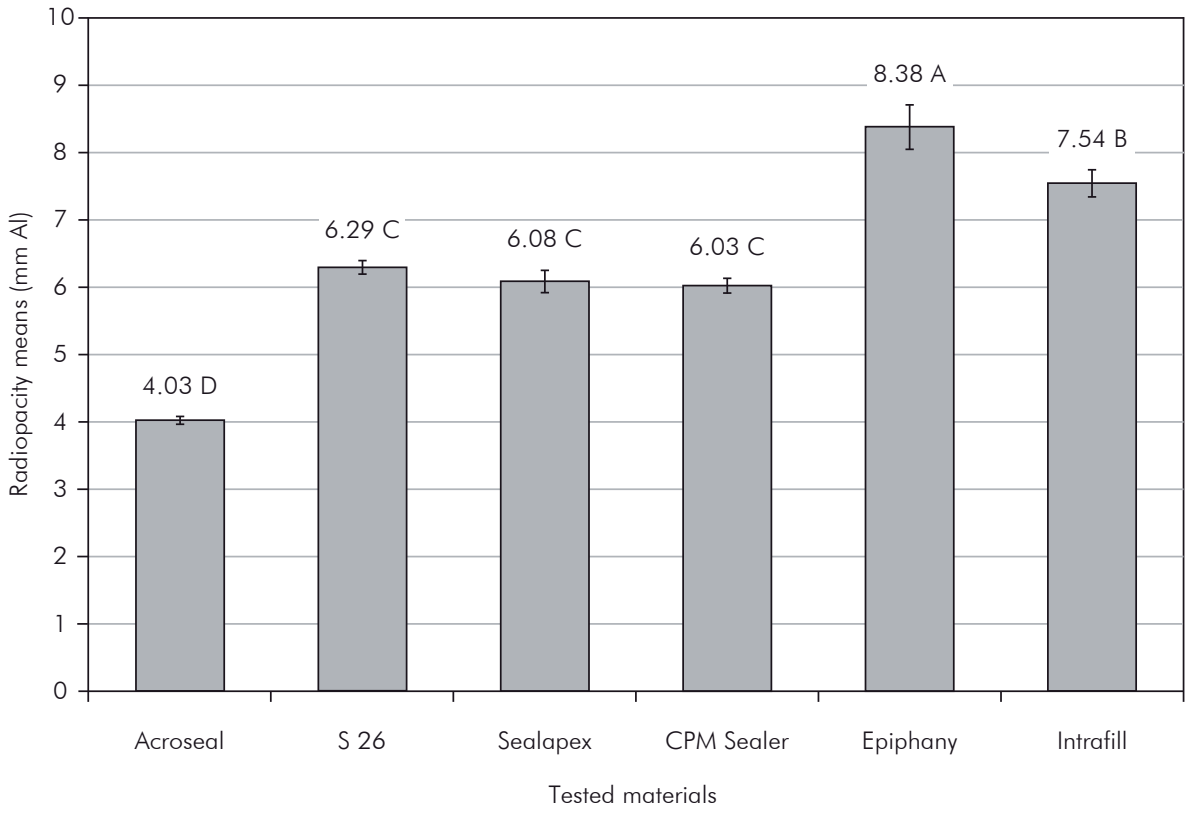

et al. ${ }^{18}$ (2007) using a similar methodology.

Sealer $26(6.3 \mathrm{mmAl})$, Sealapex $(6.1 \mathrm{mmAl})$ and Endo CPM Sealer $(6 \mathrm{mmAl})$ presented similar radiopacity. Sealer 26 contains bismuth trioxide, acting as the sealer radiopaque substance. ${ }^{9}$

The new formulation of Sealapex had greater radiopacity than the former formulation ${ }^{9}$ due to the addition of bismuth trioxide to its composition. Bismuth trioxide replaced the barium sulfate present in the original formulation.

The MTA-based material, Endo CPM Sealer, had a satisfactory radiopacity value. Bismuth trioxide and barium sulfate are added to the material to provide radiopacity. Therefore, a material's radiopacity is compatible with its application as a root canal sealer.

Acroseal was less radiopaque than the other materials and its radiopacity is related to the presence of bismuth subcarbonate in its formulation. However, its radiopacity $(4 \mathrm{mmAl})$ is in compliance with the specifications of the ISO standard.

\section{Conclusions}

The root canal sealers containing calcium hydroxide and MTA presented different radiopacities. However, all materials presented radiopacity values above the minimum recommended by the ISO standard. 


\section{References}

1. Beyer-Olsen EM, Orstavik D. Radiopacity of root canal sealers. Oral Surg Oral Med Oral Pathol. 1981;51(3):320-8.

2. Imai Y, Komabayashi T. Properties of a new injectable type of root canal filling resin and adhesiveness to dentin. J Endod. 2003;29(1):20-3.

3. Katz A, Kaffe I, Littner M, Tagger M, Tamse A. Densitometric measurement of radiopacity of gutta-percha cones and root dentin. J Endod. 1990;16(5):211-3.

4. McComb D, Smith DC. Comparison of physical properties of polycarboxylate-based and conventional root canal sealers. J Endod. 1976;2(8):228-35.

5. Eliasson ST, Haasken B. Radiopacity of impression materials. Oral Surg Oral Med Oral Pathol. 1979;47(5):485-91.

6. Tanomaru-Filho M, Jorge EG, Guerreiro-Tanomaru JM, Gonçalves M. Radiopacity evaluation of new root canal filling materials by digitalization of images. J Endod. 2007;33(3):24951.

7. Duarte MA, Demarchi ACO, Moraes IG. Determination of $\mathrm{pH}$ and calcium ion release provided by pure and calcium hydroxide-containing AH Plus. Int Endod J. 2004;37(1):425.

8. Holland R, Souza V. Ability of a new calcium hydroxide root canal filling material to induce hard tissue formation. J Endod. 1985;11(12):535-43.

9. Tanomaru JMG, Cezare L, Gonçalves M, Tanomaru-Filho M. Evaluation of the radiopacity of root canal sealers by digitalization of radiographic images. J Appl Oral Sci. 2004;12(4):355-7.

10. Leonardo MR, da Silva LA, Utrilla LS, Assed S, Ether SS. Calcium hydroxide root canal sealers - histopathologic evaluation of apical and periapical repair after endodontic treatment. J Endod. 1997;23(7):428-32.

11. Ungor M, Onay EO, Orucoglu H. Push-out bond strengths: the Epiphany-Resilon endodontic obturation system compared with different pairings of Epiphany, Resilon, AH Plus and gutta-percha. Int Endod J. 2006;39(8):643-7.

12. Leonardo MR, Barnett F, Debelian GJ, de Pontes Lima RK, Bezerra da Silva LA. Root canal adhesive fillings in dog's teeth with or without coronal restoration: a histopathological evaluation. J Endod. 2007;33(11):1299-303.

13. Antunes Bortoluzzi E, Juárez Broon N, Antonio Hungaro Duarte M, de Oliveira Demarchi AC, Monteiro Bramante $\mathrm{C}$. The use of a setting accelerator and its effect on $\mathrm{pH}$ and calcium ion release of Mineral Trioxide Aggregate and white Portland cement. J Endod. 2006;32(12):1194-7.

14. Holland R, Souza V, Nery MJ, Otoboni Filho JA, Bernabé PFE, Dezan Junior E. Reaction of rat connective tissue to implanted dentin tube filled with mineral trioxide aggregate and calcium hydroxide. J Endod. 1999;25(3):161-6.

15. Holland R, Souza, V, Nery, MJ, Faraco Junior IM, Bernabé PFE, Otoboni Filho JA et al. Reaction of rat connective tissue to implanted dentin tube filled with Mineral Trioxide Aggregate, Portland Cement and Calcium Hydroxide. Braz Dent J. 2001;12(1):3-8.

16. Ferreira MB, Kairalla E, Hoshina R, Lage-Marques JL. Análise de espectrometria de fluorescência de Raios-X e Difratometria de Raios-X dos sealers MTA, CPM e CPM Sealer. Braz Oral Res. 2005;19(Suppl):165.

17. Tagger M, Katz A. The radiopacity of endodontic sealers: development of a new method for direct measurement. J Endod. 2003;29(11):751-5.

18. Carvalho Júnior JR, Correr-Sobrinho R, Correr AB, Sinhoreti MA, Consani S, Souza-Neto MD. Radiopacity of root filling materials using digital radiography. Int Endod J. 2007;40(7):514-20.

19. International Organization for Standardization ISO 6876 - 2001. Dental root sealing materials.

20. American Dental Association. Specification no. 57 for endodontic filling materials. J Am Dent Assoc. 1984;108:88. 